\title{
Qualitative evaluation of fermented olives grown in Southern Italy (cvs. Carolea, Grossa of Gerace and Nocellara Messinese)
}

\author{
Alessandra De Bruno*, Angela Zappia, Amalia Piscopo, Marco Poiana \\ Department of AGRARIA, University Mediterranea of Reggio Calabria, 89124 Vito, Reggio Calabria, Italy
}

\section{A B S T R A C T}

\begin{abstract}
The aim of this work was to evaluate the quality of olives of three typical cultivars of Southern Italy and correspondent brines after different fermentation variables: two $\mathrm{NaCl}$ concentrations with and without acidification up to $\mathrm{pH} 4$ ). In particular, physicochemical parameters, microbiological counts and antioxidant activity of olive samples and brines were monitored and compared. The obtained results showed a good fermentation performance of studied olive cultivars, with a brine $\mathrm{pH}$ inside the legal limit of 4.3 , also in samples were the $\mathrm{pH}$ correction was not performed. The $\mathrm{pH}$ lowering was slower in brine samples treated with the lowest salt concentration. Moreover, all samples manifested higher antioxidant activity after 240 days of brining, and total phenol content ranged from 9.22 to $20.78 \mathrm{~g}$ gallic acid $\mathrm{kg}^{-1}$ in olives. Among samples, Carolea olives showed the highest total phenolic content and the highest antioxidant activity after 240 days of fermentation.
\end{abstract}

Keywords: Antioxidant capacity; Brining; Phenolic compounds; Table olives.

\section{INTRODUCTION}

Table olives are one of the most popular fermented traditional food products in Mediterranean countries and their world consumption is continuously increasing. Spain, Greece, and Italy are among the world's leading manufacturers, together supply almost $30 \%$ of annual world olive production which exceeds 2.4 million tons/year (IOC 2016; Rodríguez-Gómez et al., 2017). Italy is the third most important producer in the world; with about 96,000 tons/year of table olives (D'Antuono et al., 2018).

Olives, represent an important source of nutrients and bioactive compounds with health benefits due to the presence of high level of mono-unsaturated fatty acids and phenolic compounds (Gamli, 2016). The composition of some chemical constituents, as phenolic compounds, and also biometric parameters of olive fruits and derived products are affected by several factors as: geographical origin (Garcìa et al., 2018; Piscopo et al., 2016a), variety (Romero et al., 2004; Giuffrè, 2017), degree of olive ripeness (Piscopo et al., 2018a; Conte et al., 2019) and processing (Mele et al., 2018; Piscopo et al., 2018b; Sicari et al., 2010; Romeo et al., 2009; Pires-Cabral et al. 2018). The unprocessed table olives are rich in oleuropein and ligstroside, compounds responsible of their characteristic bitter taste (Ryan and Robards, 1998), so they undergo transformation processes to be more palatable (Aka-Kayguluoglu et al., 2014; Piscopo et al., 2014). One of the most important steps in the production of table olives is degradation of their excessively high levels of polyphenolic compounds (Cosmai et al., 2018). The aim of table olive processing is to hydrolyse the oleuropein by different treatments, for example the olives can be treated in sodium hydroxide solutions, put into brine and successively rinsed in water, or they can also be directly fermented in brine (natural method or spontaneous fermentation) (Aponte et al., 2010; Fadda et al., 2014; Piscopo et al., 2016b; Romeo et al., 2012). Spontaneous fermentation lasts 8-12 months and it is carried out by population of several microorganisms, mainly the epiphytic yeasts and lactic acid bacteria (LAB) (Brenes et al., 2004; Garrido Fernández et al., 1997; Medina et al., 2008), which play an important role in the production of treated and

\footnotetext{
*Corresponding author:

Alessandra De Bruno, Department of AGRARIA, University Mediterranea of Reggio Calabria, 89124 Vito (Reggio Calabria), Italy.

Tel.: +39 09651694381/2. E-mail: alessandra.debruno@unirc.it
}

Received: 11 April 2019; Accepted: 29 July 2019 
natural table olives (Arroyo-López et al., 2012; Sidari et al., 2019). As reported by Romeo et al. (2010), the successful fermentation of brined vegetables is influenced by numerous chemical and physical factors, including: cultivar, the skin colour, the flesh firmness of the drupe and the time of processing. Besides the use of starter cultures and different salt levels, the application of acidified solution, could be an alternative to preserve the product.

To this purpose, the aim of the present study was to determine the influence of different treatments such as acidification and salt addition on the quality of table olives. These treatments were performed on three cultivars typical of southern Italy, namely Carolea, Grossa of Gerace and Nocellara Messinese, in order to study the fermentative evolution and to define the better method to obtain table olives with improved sensorial, textural and microbiological quality for the studied cultivar.

\section{MATERIALS AND METHODS}

\section{Materials}

Olives from Carolea (C), Grossa of Gerace (G) and Nocellara Messinese $(\mathrm{N})$ cultivars were harvested in the province of Reggio Calabria (Italy) at mature-green stage and immediately transported to the laboratory to be processed. Calibration by weight was performed to have uniform fruit sizes and carpological analyses were carried out on 50 fruits randomly sampled within the lot. Moisture content $(\mathrm{MC})$, water activity $\left(\mathrm{a}_{\mathrm{w}}\right), \mathrm{pH}$, Titratable acidity (TA), Total Soluble Solids (TSS), Total Phenolic Compounds (TPC) and DPPH assay were carried out on fresh olives.

\section{Olive processing}

After washing, the olives were subjected to natural fermentation. The lab-scale fermentations were performed in cylindrical fermenters made of polyethylene $(11 \mathrm{~kg}$ olives in $16.5 \mathrm{~L}$ of brine): each fermentation was performed twice (Fig. 1 a,b).

The experimental plan adopted different levels of salt concentration ( 5 and $8 \% \mathrm{NaCl}$ ) and the acidification with lactic acid $(90 \%$, Fluka) to $\mathrm{pH} 4.3$ or no acidification. The containers were filled up with fresh prepared brine and the samples were named with the initial " $C$ " for Carolea $c v$, "G" for Grossa of Gerace $c v$ and "N" for Nocellara Messinese cv followed as reported below:

- $8 \% \mathrm{NaCl}$ not acidified brine ( $8 \% \mathrm{NA})$;

- $\quad 8 \% \mathrm{NaCl}$ acidified brine ( $8 \% \mathrm{~A})$;

- $5 \% \mathrm{NaCl}$ for 20 days and the salt concentration was after increased to $8 \%$ not acidified brine ( $5 \%$ NA);

- $5 \% \mathrm{NaCl}$ for 20 days and the salt concentration was after increased to $8 \%$ acidified brine ( $5 \% \mathrm{~A})$.

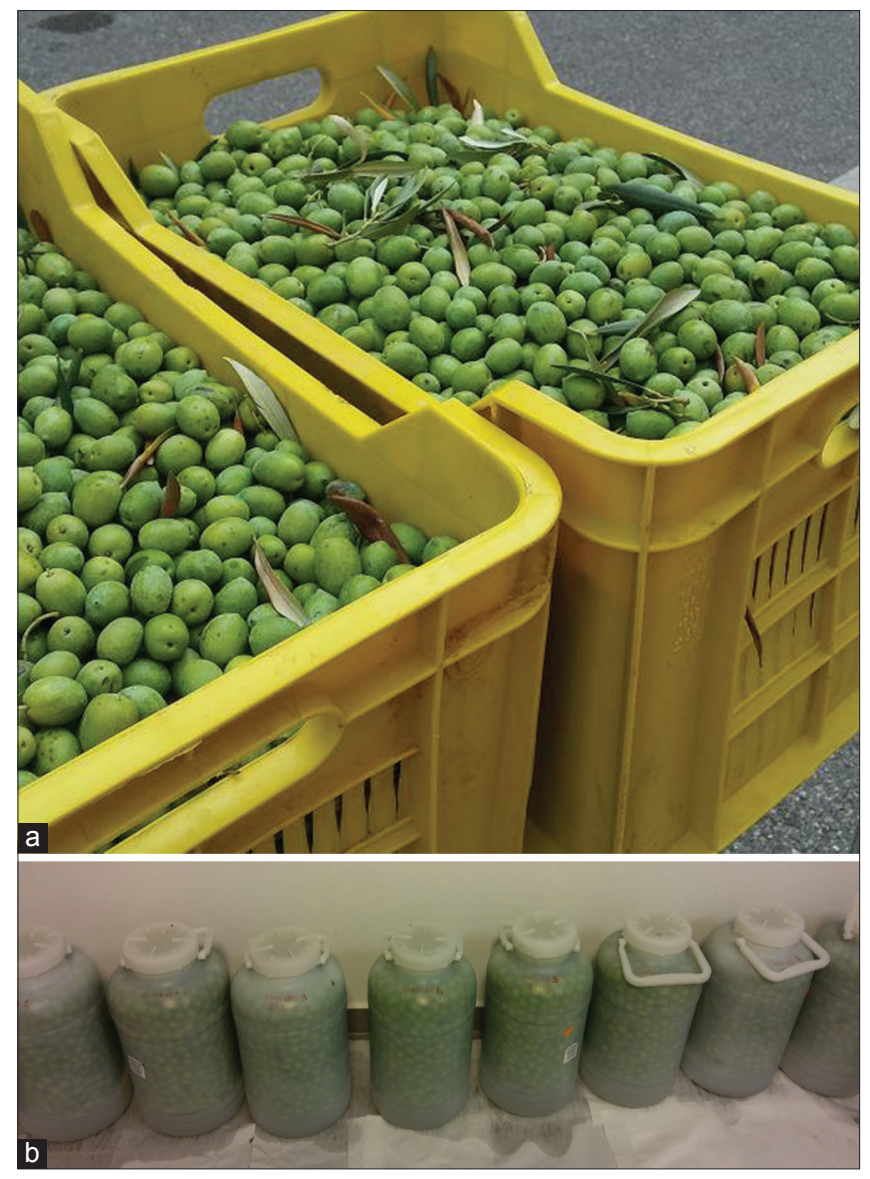

Fig 1. (a) Carolea olives before the treatments, (b) Carolea olives during the brining process.

The olives were brined at ambient temperature, adopting correction of salinity and acidity for 8 months during different time corresponding to $7,15,30,45,90,120$, 180, 240 days. The salt concentration and $\mathrm{pH}$ values in the brines were adjusted respectively by adding solid $\mathrm{NaCl}$ and lactic acid to guarantee good preservation during the post fermentation stage.

\section{Methods}

Physicochemical and microbiological analyses of brines

Analyses of brines for $\mathrm{pH}$ and Total Acidity (TA) were carried out by the routine methods (FernándezDiez et al., 1985); while chlorides analysis (\% $\mathrm{NaCl})$ through the use of a digital refractometer (DBR 047 SALT), in order to correct salt and maintain the concentration at $8 \%$ over time. The analysis of the colour was performed on $10 \mathrm{~mL}$ of brine using a reflection colorimeter (Minolta CR 300, Osaka, Japan) with reference to CIE L*a*b* coordinates by using of a D65 illuminant. The viable populations of the principal groups of microorganisms were determined by plating the brines. In the following selective media: total mesophilic bacteria in Plate Count Agar (Oxoid) (PCA) incubated at $32{ }^{\circ} \mathrm{C}$ for $24 \mathrm{~h}$, lactic acid bacteria in MRS 
Agar (LAB) (Oxoid) added with $50 \mathrm{mg} / \mathrm{L}$ of Nystatin at $32^{\circ} \mathrm{C}$ for $48 \mathrm{~h}$ in anaerobiosis, yeasts and moulds in OGYA (Oxoid) at $25^{\circ} \mathrm{C}$ for $48 \mathrm{~h}$ (expressed as $\log _{10} \mathrm{CFU} \mathrm{mL} \mathrm{mL}^{-1}$ ).

\section{Physicochemical analyses of olives}

For $\mathrm{pH}$ and free acidity values were carried out by the routine methods (Fernández-Diez et al., 1985) and the results were expressed as $\mathrm{g}$ Lactic acid $100 \mathrm{~g}^{-1}$ olives). $\mathrm{a}_{\mathrm{w}}$ was measured by an Aqua lab (3TE, Decagon devices Inc., Washington) apparatus which uses the chilled-mirror dew point technique to measure the $a_{w}$ of homogenized samples. MC was determined by oven drying at $105^{\circ} \mathrm{C}$ up to constant weight. The colour of the olives was measured using a reflection colorimeter (Minolta CR 300, Osaka, Japan) with reference to CIE $\mathrm{L}^{*} \mathrm{a} * \mathrm{~b} *$ coordinates. This analysis was assessed on two points of each olive and for ten olives randomly chosen for each sample.

\section{Total phenol content (TPC) and antioxidant activity of olives and brines}

The olive extracts were obtained according to the method reported by Othman et al. (2009), with some modifications. The TPC of olive extracts and brines were quantified spectrophotometrically at $725 \mathrm{~nm}$ after reaction with the Folin Ciocalteu reagent. The results were obtained by means of a calibration plot using pure gallic acid as standard at different concentrations and expressed as $g$ gallic acid equivalent (GAE) $\mathrm{kg}^{-1}$ of fresh weight (f.w.) for olives and $\mathrm{mg}$ gallic acid equivalent (GAE) $\mathrm{L}^{-1}$ for brines.

The total antioxidant activity determination was performed using the Brand-Williams et al. (1995) method. The decrement of absorbance was determined by a spectrophotometer at $515 \mathrm{~nm}$ (after 30 minutes) at the temperature of $20^{\circ} \mathrm{C}$ to eliminate the risk of thermal degradation of the molecules tested (Bondet et al., 1997). The results were expressed as percentage of inhibition and calculated by applying the following formula:

$$
\% \text { Inhibition }=\left(\left(\mathrm{At}_{0}-\mathrm{At}_{\mathrm{e}}\right) / \mathrm{At}_{0}\right) * 100
$$

Moreover, the Trolox Equivalent Antioxidant Capacity (TEAC) method was performed using the method reported by Re et al. (1999). The decrement of absorbance was measured after 6 minutes at $734 \mathrm{~nm}$. The TEAC value was expressed as $\mu \mathrm{M}$ Trolox $\mathrm{g}^{-1}$.

\section{Sensory analysis}

The procedure for the classification of table olives is based on official parameters of quality (IOC, 2011). The test was performed by a panel of 8 judges (males and females) from 25 to 50 years old, recruited among researchers and technicians of the Food Science and Technology Unit of
Reggio Calabria University with previous experience in the sensory analysis of table olives. The guidelines for taster and panel leader training in accordance with IOC standard (IOC, 2011) were used for the sensory analysis of table olives. The judges were trained during some preliminary sessions for identification of gustatory attributes (saltiness, bitterness, acidity) and for kinaesthetic or texture attributes (hardness, fibrousness, crunchiness). Sensory data were elaborated by calculating the median of results. The principles of Quantitative Descriptive Analysis (QDA) were utilized to define the typical sensory profile of each end-product.

\section{Statistical analysis}

All experimental results in this study were expressed as mean values \pm standard deviation $(\mathrm{SD})$ of three measurements $(\mathrm{n}=3)$. The significant differences $(\mathrm{p}<0.05)$ among treatment means were determined by analysis of variance (Multivariate and ANOVA analysis) with Tukey's post-hoc test. SPSS Software (Version 15.0, SPSS Inc., Chicago, IL, USA) was used for data processing. In addition, Pearson's correlation coefficients ( $r$ ) to determine the relation between two variables were analysed.

\section{RESULTS AND DISCUSSIONS}

\section{Physicochemical characteristics of fresh olives}

The characteristics of fresh olives of three cultivars have been reported in Table 1.

The carpological parameters of two samples (Carolea and Nocellara Messinese) reveal that are suitable for processing as table olives according to the IOC (2000) limits that define the olive's suitability for table consumption in function of weight between 3 and $5 \mathrm{~g}$. The size is in fact important for the product presentation and olives showed different weight among cultivars: $2.35 \mathrm{~g}, 3.42 \mathrm{~g}$ and 3.69 respectively in $G, N$ and $C$. The flesh to pit ratio equal or higher to 4 and a percentage of flesh higher than 80 respect the whole fruit are considered optimal for table olives with No significant differences were observed among the three cultivars which showed a ratio near $4 \%(\mathrm{p}>0.05)$.

Some differences were instead observed among cultivars for MC percentage $(p<0.05)$, in particular the olives of Nocellara Messinese $c v$ showed the highest moisture content $(75.62 \% \pm 0.62)$, whereas cultivars did not differ for $\mathrm{a}_{\mathrm{w}}$ and $\mathrm{pH}$ value $(\mathrm{p}>0.05)$. The brining promoted the release of water, sugar and other nutrients from olives. TSS are an interesting parameters because the olive sugars transferred into the brine. make it an appropriate growth medium for the microorganisms responsible for lactic fermentation (Maldonado et al., 2008). Carolea olives showed the higher total soluble content $3.17^{\circ}$ Brix than other samples before 
Table 1: Compositional characteristics of fresh olives of the three cultivars

\begin{tabular}{|c|c|c|c|c|}
\hline & Carolea & Grossa of Gerace & Nocellara & Sign. \\
\hline Fruit length $(\mathrm{mm})$ & $23.3 \pm 0.17^{a}$ & $19.8 \pm 0.20^{c}$ & $21.7 \pm 0.19^{b}$ & ** \\
\hline Fruit diameter (mm) & $16.7 \pm 0.14^{\mathrm{a}}$ & $13.9 \pm 0.15^{b}$ & $16.5 \pm 0.15^{\mathrm{a}}$ & ** \\
\hline Fruit weight (g) & $3.69 \pm 0.76^{a}$ & $2.35 \pm 0.62^{b}$ & $3.42 \pm 0.84^{a}$ & ** \\
\hline Flesh/pit ratio & $4.00 \pm 1.29$ & $3.73 \pm 1.24$ & $3.47 \pm 1.00$ & n.s. \\
\hline $\mathrm{MC}(\%)$ & $66.09 \pm 1.03^{b}$ & $67.91 \pm 0.96^{b}$ & $75.62 \pm 0.62^{\mathrm{a}}$ & ** \\
\hline$a_{w}$ & $0.996 \pm 0.001$ & $0.997 \pm 0.002$ & $0.996 \pm 0.001$ & n.s. \\
\hline TA (\% lactic acid) & $0.44 \pm 0.04^{a}$ & $0.25 \pm 0.03^{c}$ & $0.33 \pm 0.03^{b}$ & ** \\
\hline $\mathrm{pH}$ & $5.36 \pm 0.03$ & $5.39 \pm 0.01$ & $5.40 \pm 0.04$ & n.s. \\
\hline TSS ( ${ }^{\circ}$ brix) & $3.17 \pm 0.06^{\mathrm{a}}$ & $2.97 \pm 0.06^{b}$ & $3.07 \pm 0.06^{\mathrm{ab}}$ & * \\
\hline TPC (g Gallic acid kg-1) & $25.68 \pm 3.35^{a}$ & $19.68 \pm 1.89^{b}$ & $23.29 \pm 2.62^{\mathrm{ab}}$ & * \\
\hline DPPH (\% Inactivation) & $24.38 \pm 1.45^{\mathrm{a}}$ & $20.23 \pm 1.95^{b}$ & $21.81 \pm 1.37^{\mathrm{ab}}$ & * \\
\hline
\end{tabular}

The data are presented as means \pm SDs. ${ }^{\star \star}$ Significance at $p<0.01 ;{ }^{\star}$ Significance at $p<0.05$; n.s. not significant.

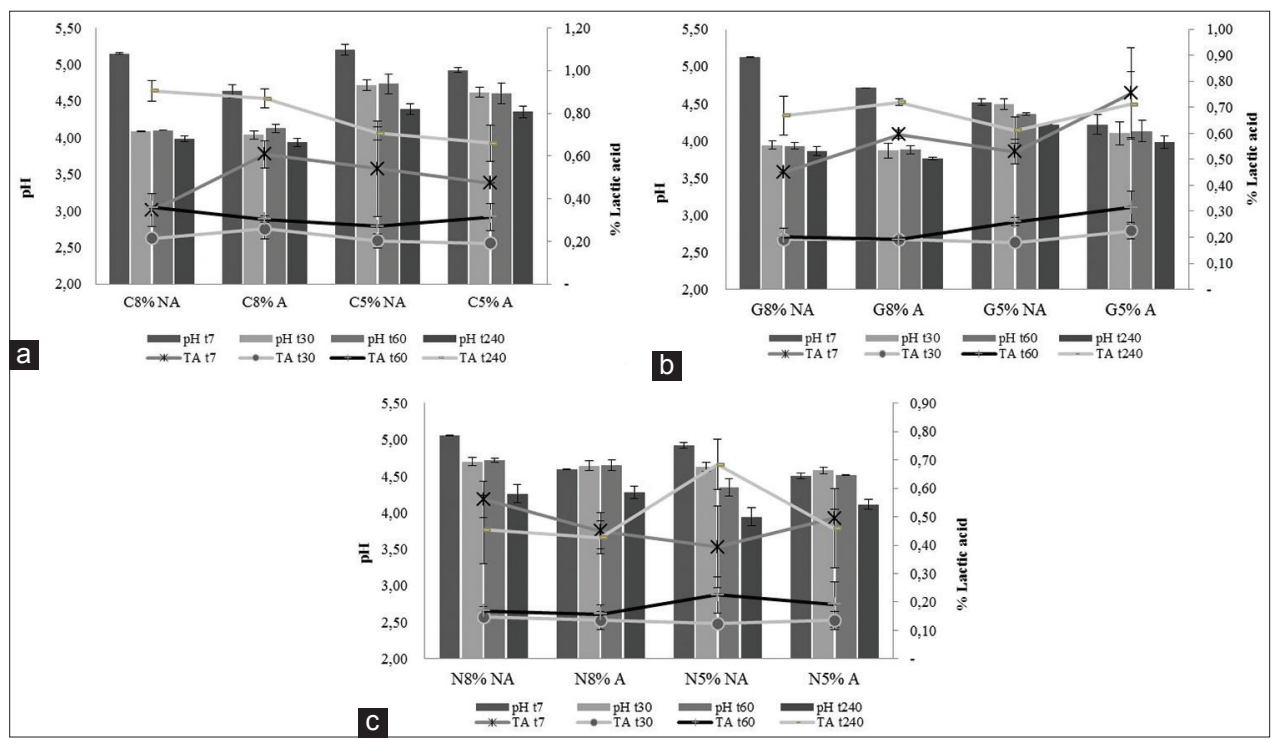

Fig 2. Changes in pH value in brine during fermentation of Carolea (a), Grossa of Gerace (b) and Nocellara Messinese (c) olives. Legenda: $\mathrm{C}=$ Carolea; $\mathrm{G}=$ Geracese; $\mathrm{N}=$ Nocellara Messinese; $\mathrm{A}=$ acidified; $\mathrm{NA}=$ not acidified.

the brining.

Total phenolic compounds (TPC) and antioxidant capacity of fresh olives were determined in the different cultivars. Significant differences were found between the cultivars for the TPC and DPPH assays $(\mathrm{p}<0.05)$. The Carolea $c v$ showed higher values for both antioxidant assays (TPC: $25.68 \pm 3.35$ and DPPH: $24.38 \pm 1.45$ ); follows the Nocellara Messinese $c v$ with slightly lower values (TPC: $23.29 \pm 2.62$; DPPH: $21.81 \pm 1.37$ ); while lower values were detected in Grossa of Gerace $c v$ (TPC: 19.68 \pm 1.89; DPPH: $20.23 \pm 1.95$ ).

\section{Physicochemical characteristics and antioxidant capacity of brine during fermentation}

The colour parameters were measured in brine samples at the end of fermentation: significant differences were observed among samples for the brightness value $\left(\mathrm{L}^{*}\right)$, that increased in all samples after 240 days of fermentation. The same trend was observed for $\mathrm{b}^{*}$ value, denoting a tendency to the yellow tone at the end of fermentation, whereas the measured $a^{*}$ values generally did not strongly differ during the time. The $\Delta \mathrm{E}^{*}$ parameter, that measures the colour differences, was significantly different among all the treated olives. The highest value (10) was found in Grossa of Gerace $c v$ (data not shown).

$\mathrm{pH}$ and $\mathrm{TA}$ values were also monitored as indicators of the evolution of the fermentation (Fig. 2 a,b,c, Table 2). The $\mathrm{pH}$ of brine is an important parameter in technological and safety terms, and the measured values were lower than the limits (4.3) for marketing table olives in most of the samples (IOC, 2004). The $\mathrm{pH}$ values decreased more clearly and particularly in Carolea and Geracese $c v$. within the first 30 days of fermentation, also in not acidified samples. These cultivars, treated with a higher concentration of salt with 


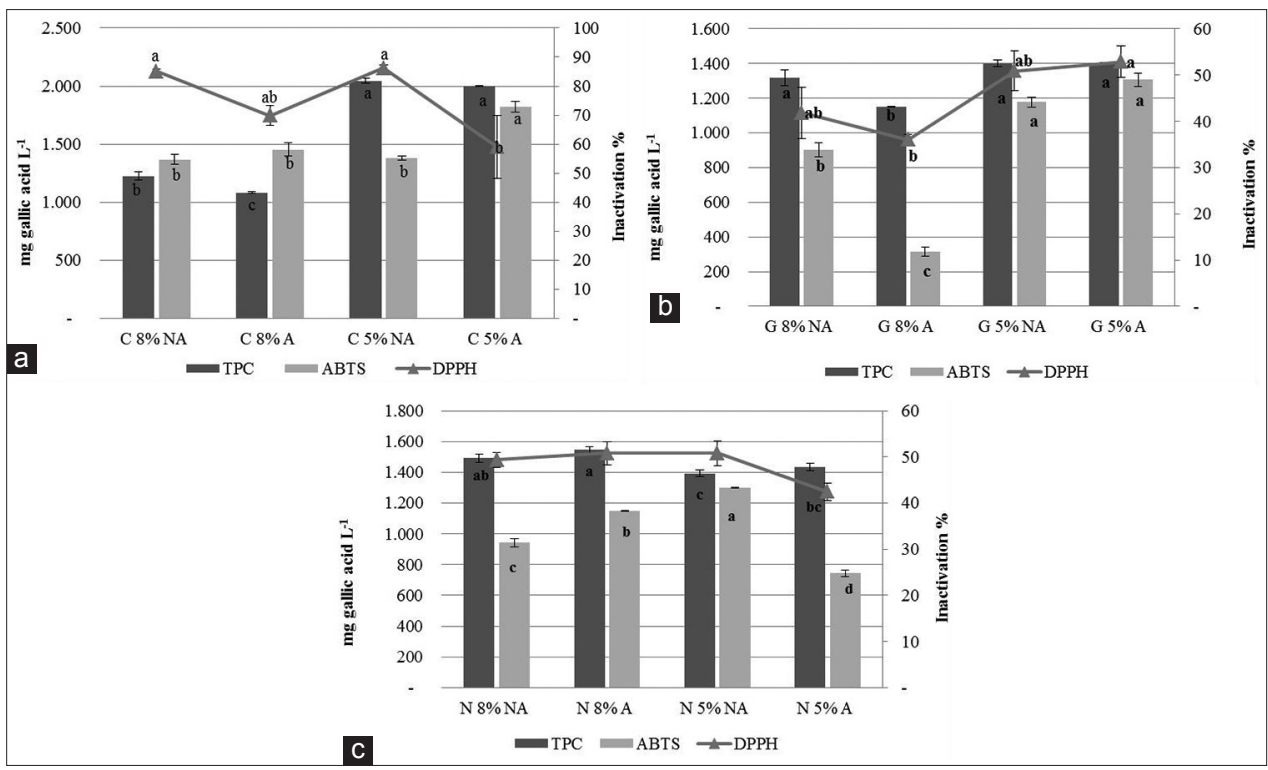

Fig 3. TPC and antioxidant activity in brines after 240 days in Carolea (a), Grossa of Gerace (b) and Nocellara Messinese (c) $c v$. The data are presented as means \pm SDs. ${ }^{*}$ Significance at $P<0.01$; ${ }^{*}$ Significance at $P<0.05$; n.s. not significant

Table 2: Results of Tukey's post-hoc test for pH and TA analysis on brines of treated olives

\begin{tabular}{|c|c|c|c|c|c|}
\hline Analysis & Cultivars & $8 \%$ NA & $8 \% \mathrm{~A}$ & $5 \%$ NA & $5 \% \mathrm{~A}$ \\
\hline $\mathrm{pH}$ & C & ** & ns & ** & * \\
\hline $\mathrm{pH}$ & G & ** & ** & ** & ns \\
\hline $\mathrm{pH}$ & $\mathrm{N}$ & ** & ns & * & ** \\
\hline TA & C & ** & ** & ** & * \\
\hline TA & $\mathrm{G}$ & ** & ** & ** & ** \\
\hline TA & $\mathrm{N}$ & ** & ** & ** & * \\
\hline
\end{tabular}

and without acidification, showed a $\mathrm{pH}$ decrease from 5 to 4 after 30 days of brining). Moreover, no further significant variations were observed up to 240 days of fermentation. A different trend was found for Nocellara Messinese $c v$, where the safety parameters have been reached at the end of fermentation (240 days, Fig. 2c). The TA values increased progressively during the fermentation process, with a corresponding decrease in $\mathrm{pH}$, which reached values of $4.1-4.3$ at the end of fermentation (8 months). The increase in acidity from 180 to 240 days, showed in all the treated samples, was very important to prevent microbial spoilage and for a general accuracy of the fermentative process, as reported by other authors (Sánchez et al., 2018). Therefore, both acidified and no acidified olives showed in this experimentation a correct fermentation according to the microbiological rule for table olives parameters (IOC, 2004).

The counts of PCA, LAB, yeasts and moulds are shown in Table 3. The microbiological analysis at the end of fermentation did not show significant differences for Carolea and Grossa of Gerace cvs ( $\mathrm{p}>0.05$ ), only the moulds were significant in all the olives treated $(\mathrm{p}<0.01)$. All the samples showed a reduction of PCA during the
Table 3: Microbiological analysis of brines (expressed as Log10 CFU mL-1) after 240 days of the three cultivars

\begin{tabular}{|c|c|c|c|c|c|c|}
\hline Analysis & Cultivars & $8 \%$ NA & $8 \% \mathrm{~A}$ & $5 \%$ NA & $5 \% A$ & Sign. \\
\hline \multirow[t]{4}{*}{ PCA } & C & $5.36^{b}$ & 5.46 & $5.15^{b}$ & 5.43 & ns \\
\hline & $\mathrm{G}$ & $5.41^{b}$ & 5.34 & $5.24^{\mathrm{b}}$ & 5.69 & ns \\
\hline & $\mathrm{N}$ & $5.80^{\mathrm{aA}}$ & $5.15^{\mathrm{C}}$ & $5.65^{a A B}$ & $5,44^{\mathrm{B}}$ & $* *$ \\
\hline & Sign. & * & $\mathrm{ns}$ & ** & ns & \\
\hline \multirow[t]{4}{*}{ LAB } & C & $5.26^{b}$ & 5.49 & $5.26^{\mathrm{b}}$ & 5.29 & ns \\
\hline & $G$ & $5.31^{\mathrm{bAB}}$ & $5.30^{\mathrm{AB}}$ & $5.21 b^{B}$ & $5.42^{\mathrm{A}}$ & * \\
\hline & $\mathrm{N}$ & $5.81^{\mathrm{aA}}$ & $5.17^{\mathrm{C}}$ & $5.61 a^{\mathrm{AB}}$ & $5.43^{\mathrm{BC}}$ & ** \\
\hline & Sign. & * & ns & ** & ns & \\
\hline \multirow[t]{4}{*}{ Moulds } & C & $\mathrm{OB}$ & $O c^{B}$ & $0 b^{B}$ & $3.48^{\mathrm{aA}}$ & ** \\
\hline & $G$ & $\mathrm{OB}$ & $3.69^{\mathrm{aA}}$ & $O b^{B}$ & $3.3^{\mathrm{aA}}$ & ** \\
\hline & $\mathrm{N}$ & $\mathrm{OD}$ & $3.48^{\mathrm{bB}}$ & $3.96^{\mathrm{aA}}$ & $3.00^{\mathrm{bc}}$ & ** \\
\hline & Sign. & ns & ** & ** & $* *$ & \\
\hline \multirow[t]{4}{*}{ Yeast } & C & $4.25^{\mathrm{bB}}$ & $4.84^{\mathrm{A}}$ & $4.61 b^{A B}$ & $4.31^{\mathrm{AB}}$ & ns \\
\hline & $G$ & $4.80^{\mathrm{a}}$ & $4.48^{b}$ & $4.39^{b}$ & 4.63 & ns \\
\hline & $\mathrm{N}$ & $5.06^{\mathrm{aB}}$ & $4.61^{\mathrm{abc}}$ & $6.03^{\mathrm{aA}}$ & $4.81^{\mathrm{BC}}$ & ** \\
\hline & Sign. & * & * & ** & ns & \\
\hline
\end{tabular}

The data are presented as means \pm SDs. ${ }^{* *}$ Significance at $\mathrm{p}<0.01$.

* Significance at $p<0.05 ;$ n.s. not significant. By Tukey's multiple range test small letters show differences among the cultivars and capital letters show differences among the treatments.

monitoring time (data not shown). After 240 days of fermentation the samples showed values between 5.15 and 5.80 ( $\log 10$ CFU mL-1), significant differences were found for Nocellara Messinese $c v$ and for samples treated without acidification. $\mathrm{LAB}$ were present from the first weeks of fermentation in all cultivars and their contents were higher than yeasts: this showed that fermentation has taken place 
Table 4 (a): Results of multivariate analysis for some physicochemical, microbiological and antioxidant parameters respect to different factors on brines

\begin{tabular}{|c|c|c|c|c|c|c|c|}
\hline Brines & Cultivar & Treatments & Storage time & $C * T$ & $C^{*} \mathrm{St}$ & $T * S t$ & $C^{*} T^{*} S t$ \\
\hline $\mathrm{pH}$ & ** & ** & ** & ** & * & ns & ns \\
\hline TA & ** & ns & ** & ** & ** & ns & ns \\
\hline PCA & ** & ** & ** & ** & ** & ** & ** \\
\hline LAB & ** & ** & ** & ** & ** & ** & ** \\
\hline ABTS & ** & ** & ** & ** & ** & * & ** \\
\hline DPPH & ** & ** & ** & ** & ** & ** & ** \\
\hline TPC & ** & ** & ** & ** & * & ** & ** \\
\hline
\end{tabular}

${ }^{\star \star}$ Significance at $p<0.01$; ${ }^{*}$ Significance at $p<0.05$; n.s. not significant.

\begin{tabular}{|c|c|c|c|c|c|c|c|}
\hline Olives & Cultivar & Treatments & Storage time & $C^{*} T$ & $C^{*} S t$ & $T^{*} \mathrm{St}$ & $\mathrm{C}^{*} \mathrm{~T}^{*} \mathrm{St}$ \\
\hline ss & ** & * & ** & ns & ns & ns & ns \\
\hline aw & ** & ns & ** & ns & ns & ns & * \\
\hline $\mathrm{pH}$ & ** & ns & ** & ns & $* *$ & ns & ns \\
\hline TA & ** & ns & ** & * & ** & ns & ns \\
\hline ABTS & ** & ns & * & ** & ns & ns & ** \\
\hline DPPH & ** & $\star *$ & ** & ** & $* *$ & ** & ns \\
\hline TPC & ** & ** & ** & * & ** & ** & $\mathrm{ns}$ \\
\hline
\end{tabular}

${ }^{\star \star}$ Significance at $p<0.01 ;{ }^{*}$ Significance at $p<0.05$; n.s. not significant.

adequately. However, all the brines showed a decrease of LAB during the time: probably the reduction was due to the natural competition among microbiota present in the treated olives. After 9 months of fermentation, $\mathrm{LAB}$ showed variable values from 5.17 to $5.81 \log _{10} \mathrm{CFU}$ $\mathrm{mL}^{-1}$ for all the cultivars and treatments, with statistical differences in Grossa of Gerace $(\mathrm{p}<0.05)$ and Nocellara Messinese $(\mathrm{p}<0.01)$ samples and for the not acidified samples (8\% NA and 5\% NA). Yeasts and moulds were monitored only at the end of the fermentation process. The moulds were particularly present in the samples in the acidified samples (5\% A and $8 \% \mathrm{~A})$ in all the cultivars (except for Carolea $c v)$.

TPC and antioxidant capacity in brines at the end of the monitoring period are shown in Figure $3(a, b, c)$. The level of phenolic compounds and antioxidant capacity determined with DPPH assay increased significantly during the fermentation process. The increase of these parameters was due to the diffusion of phenolics from the olive to the brine during fermentation as observed in other papers (Romeo et al., 2010; Chranioti et al., 2018). The TPC in brines showed significant differences between treatments and among cultivars and showed values that ranged from 1083 to $2046 \mathrm{mg} \mathrm{L}^{-1}$ at the end of fermentation. DPPH assay showed a similar trend to that highlighted by TPC, and particularly brines of Carolea $c v$ olives expressed the highest antioxidant activity at the end of fermentation (Fig. 3 a). Tab. 4 (a) shows that most of the monitored qualitative parameters in brines were significantly influenced by all the variables (cultivar, treatments and storage time) by Multivariate analysis $(\mathrm{p}<0.01)$.

\section{Physicochemical characteristics and antioxidant capacity of olives during fermentation}

Data of physicochemical characteristics (Table 5) of treated olives were analysed at the end of fermentation (240 days). Not significant differences of $\mathrm{pH}$ values were observed among cultivars and treatments applied: the monitored values ranged from 4.22 to 4.61 . Concerning the TA results, significant differences $(\mathrm{p}<0.05)$ were observed among cultivars and treatments with the only exception of the $5 \%$ A olives of the three cultivars that possessed the same values (0.5 Lactic acid \%).

Colour is also an important quality attribute of table olives for the consumer. In this study, the colour parameters were measured in order to evaluate the chromatic variations following the application of the four technological treatments in the different cultivars. Not significant variations were observed in the same cultivar after the treatments, but there were little differences between the cultivar especially for the chromatism $\mathrm{a}^{*}$ that in all treated $G$ olives had the highest value, reflecting a tendency to red colour.

The One-way ANOVA of TPC and antioxidant activity of fermented table olives after 240 days were represented in Table 6. The phenolic content is cultivar dependent: among studied cultivars, the highest values of TPC were counted in general in Carolea olives that showed significant differences among treatments and the highest content in olives brined with $8 \% \mathrm{NaCl}$ and acidification $(20.28 \pm 0.72$ g gallic acid $\mathrm{kg}^{-1}$ ). The lowest values were instead measured in Nocellara Messinese olives treated in $5 \% \mathrm{NaCl}$ and 
Bruno, et al.

Table 5: One-way Anova data of the effect of treatment on physicochemical analyses of the three cultivars (240 days)

\begin{tabular}{|c|c|c|c|c|c|c|}
\hline & Cultivar & $8 \%$ NA & $8 \% \mathrm{~A}$ & $5 \%$ NA & $5 \% A$ & Sign. \\
\hline \multirow{4}{*}{$\mathrm{pH}$} & C & $4.40 \pm 0.01$ & $4.43 \pm 0.04$ & $4.49 \pm 0.07$ & $4.61 \pm 0.06$ & ns \\
\hline & $\mathrm{G}$ & $4.32 \pm 0.04^{\mathrm{AB}}$ & $4.22 \pm 0.01^{B}$ & $4.47 \pm 0.04^{\mathrm{A}}$ & $4.40 \pm 0.07^{\mathrm{AB}}$ & * \\
\hline & $\mathrm{N}$ & $4.58 \pm 0.10$ & $4.42 \pm 0.11$ & $4.31 \pm 0.07$ & $4.44 \pm 0.08$ & ns \\
\hline & Sign. & ns & ns & ns & ns & \\
\hline \multirow{4}{*}{$\begin{array}{l}\text { TA (g lactic } \\
\text { acid } \\
100 \mathrm{~g}^{-1} \text { pulp) }\end{array}$} & C & $0.69 \pm 0.01^{\mathrm{aA}}$ & $0.71 \pm 0.05^{\mathrm{bA}}$ & $0.67 \pm 0.01^{\mathrm{bA}}$ & $0.51 \pm 0.03^{B}$ & * \\
\hline & $\mathrm{G}$ & $0.70 \pm 0.00^{\mathrm{aB}}$ & $1.11 \pm 0.02^{\mathrm{aA}}$ & $0.52 \pm 0.01^{b C}$ & $0.51 \pm 0.04^{c}$ & ** \\
\hline & $\mathrm{N}$ & $0.48 \pm 0.04^{\mathrm{bB}}$ & $0.61 \pm 0.08^{\mathrm{bB}}$ & $1.20 \pm 0.13^{\mathrm{aA}}$ & $0.55 \pm 0.07^{\mathrm{B}}$ & ** \\
\hline & Sign. & ** & ** & ** & ns & \\
\hline \multirow[t]{4}{*}{$a^{w}$} & C & $0.957 \pm 0.016$ & $0.956 \pm 0.006$ & $0.952 \pm 0.001$ & $0.949 \pm 0.006$ & ns \\
\hline & $\mathrm{G}$ & $0.948 \pm 0.001^{B}$ & $0.946 \pm 0.001^{B}$ & $0.955 \pm 0.00^{2 A}$ & $0.954 \pm 0.001^{A}$ & ** \\
\hline & $\mathrm{N}$ & $0.956 \pm 0.004$ & $0.961 \pm 0.006$ & $0.968 \pm 0.007$ & $0.964 \pm 0.008$ & ns \\
\hline & Sign. & ns & ns & ns & ns & \\
\hline \multirow[t]{4}{*}{ MC (\%) } & C & $65.87 \pm 0.74^{\mathrm{bB}}$ & $67.07 \pm 0.45^{\mathrm{cAB}}$ & $69.33 \pm 0.74^{\mathrm{bA}}$ & $68.20 \pm 0.01 b^{A B}$ & * \\
\hline & $\mathrm{G}$ & $66.93 \pm 0.64^{\mathrm{bB}}$ & $70.82 \pm 0.71^{\mathrm{bA}}$ & $68.42 \pm 1.00^{\mathrm{bAB}}$ & $68.17 \pm 0.22 b^{A B}$ & * \\
\hline & $\mathrm{N}$ & $74.4 \pm 0.92^{\mathrm{aB}}$ & $74.50 \pm 0.25^{\mathrm{aB}}$ & $75.24 \pm 0.50^{\mathrm{aAB}}$ & $77.67 \pm 1.04^{\mathrm{aA}}$ & * \\
\hline & Sign. & ** & ** & ** & ** & \\
\hline \multirow[t]{4}{*}{$L^{*}$} & C & $50.24 \pm 1.68$ & $51.12 \pm 0.67^{a}$ & $49.02 \pm 0.17$ & $49.16 \pm 0.46^{a b}$ & ns \\
\hline & G & $50.11 \pm 0.47$ & $48.85 \pm 0.67^{\mathrm{ab}}$ & $49.49 \pm 0.69$ & $50.62 \pm 0.18^{a}$ & ns \\
\hline & $\mathrm{N}$ & $49.31 \pm 0.50$ & $47.96 \pm 0.53^{b}$ & $49.85 \pm 1.14$ & $48.04 \pm 0.40^{b}$ & ns \\
\hline & Sign. & ns & * & ns & * & \\
\hline \multirow[t]{4}{*}{$a^{*}$} & C & $6.51 \pm 0.12^{c}$ & $6.63 \pm 0.06^{c}$ & $5.98 \pm 0 c$ & $6.38 \pm 0.29^{c}$ & ns \\
\hline & $\mathrm{G}$ & $9.94 \pm 0.35^{a}$ & $10.40 \pm 0.37^{a}$ & $10.18 \pm 0.2^{3 a}$ & $10.26 \pm 0.40^{a}$ & ns \\
\hline & $\mathrm{N}$ & $8.16 \pm 0.42^{b}$ & $8.00 \pm 0.12^{b}$ & $8.72 \pm 0.36^{b}$ & $8.19 \pm 0.41^{b}$ & ns \\
\hline & Sign. & * & ** & ** & ** & \\
\hline \multirow[t]{4}{*}{$b^{*}$} & C & $26.54 \pm 1.26$ & $27.94 \pm 0.01^{a}$ & $24.55 \pm 0.16$ & $25.20 \pm 1.23$ & ns \\
\hline & $\mathrm{G}$ & $25.22 \pm 0.15$ & $25.26 \pm 0.02^{b}$ & $24.21 \pm 1.02$ & $24.53 \pm 0.80$ & ns \\
\hline & $\mathrm{N}$ & $25.00 \pm 1.51$ & $23.79 \pm 0.62^{b}$ & $25.35 \pm 1.45$ & $22.82 \pm 0.25$ & ns \\
\hline & Sign. & ns & ** & ns & ns & \\
\hline
\end{tabular}

The data are presented as means \pm SDs. ${ }^{* *}$ Significance at $p<0.01 .{ }^{*}$ Significance at $p<0.05 ;$ n.s. not significant. By Tukey's multiple range test, small letters show differences among cultivars and capital letters show differences among treatments.

Table 6: TPC and Antioxidant activity on treated olive samples after 240 days

\begin{tabular}{|c|c|c|c|c|c|c|}
\hline & Samples & $8 \%$ NA & $8 \% A$ & $5 \%$ NA & $5 \% A$ & Sign. \\
\hline \multirow[t]{4}{*}{ ABTS ( $\mu$ M Trolox) } & C & $2390 \pm 90^{\mathrm{aA}}$ & $2481 \pm 95^{\mathrm{aA}}$ & $1892 \pm 29^{\mathrm{abB}}$ & $2613 \pm 48^{\mathrm{aA}}$ & ** \\
\hline & $G$ & $1816 \pm 75^{\text {bв }}$ & $1890 \pm 65^{\mathrm{bB}}$ & $2166 \pm 90^{\mathrm{aA}}$ & $1643 \pm 18^{\mathrm{bB}}$ & ** \\
\hline & $\mathrm{N}$ & $1166 \pm 27^{\mathrm{CBC}}$ & $1300 \pm 54^{\mathrm{cB}}$ & $1719 \pm 66^{\mathrm{bA}}$ & $997 \pm 16^{\mathrm{cC}}$ & ** \\
\hline & Sign. & ** & ** & * & ** & \\
\hline \multirow[t]{4}{*}{ DPPH (\% Inhibition ) } & C & $39.13 \pm 1.49^{\mathrm{aA}}$ & $39.14 \pm 0.68^{\mathrm{aA}}$ & $33.67 \pm 1.43^{a \mathrm{~B}}$ & $36.03 \pm 1.44^{\mathrm{aAB}}$ & * \\
\hline & $\mathrm{G}$ & $25.03 \pm 1.16 b^{\mathrm{AB}}$ & $21.54 \pm 0.63^{\mathrm{bAB}}$ & $25.65 \pm 1.70^{\mathrm{bA}}$ & $20.84 \pm 0.84^{\mathrm{bB}}$ & * \\
\hline & $\mathrm{N}$ & $14.55 \pm 1.30^{\mathrm{cB}}$ & $17.63 \pm 0.79^{\mathrm{ВB}}$ & $28.89 \pm 1.25^{\mathrm{abA}}$ & $18.49 \pm 1.64^{\mathrm{bB}}$ & ** \\
\hline & Sign. & $\star \star$ & ** & * & ** & \\
\hline \multirow[t]{4}{*}{ TPC (g Gallic Acid kg-1) } & $\mathrm{C}$ & $19.35 \pm 0.52^{\mathrm{aA}}$ & $20.28 \pm 0.72^{\mathrm{aA}}$ & $15.31 \pm 0.49^{B}$ & $18.93 \pm 1.13^{\mathrm{aA}}$ & * \\
\hline & $G$ & $14.02 \pm 0.85^{b}$ & $15.75 \pm 0.34^{b}$ & $14.38 \pm 1.60$ & $12.47 \pm 0.78^{b}$ & $\mathrm{~ns}$ \\
\hline & $\mathrm{N}$ & $11.07 \pm 1.23^{\mathrm{bAB}}$ & $11.69 \pm 0.51^{\mathrm{CAB}}$ & $13.43 \pm 0.13^{A}$ & $9.12 \pm 0.63 b^{B}$ & * \\
\hline & Sign. & $\star *$ & $\star *$ & ns & ** & \\
\hline
\end{tabular}

The data are presented as means \pm SDs. ${ }^{*}$ Significance at $\mathrm{p}<0.01 .{ }^{*}$ Significance at $<0.05 ;$ n.s. not significant. By Tukey’s multiple range test, small letters show differences among cultivars and capital letters show differences among treatments. 


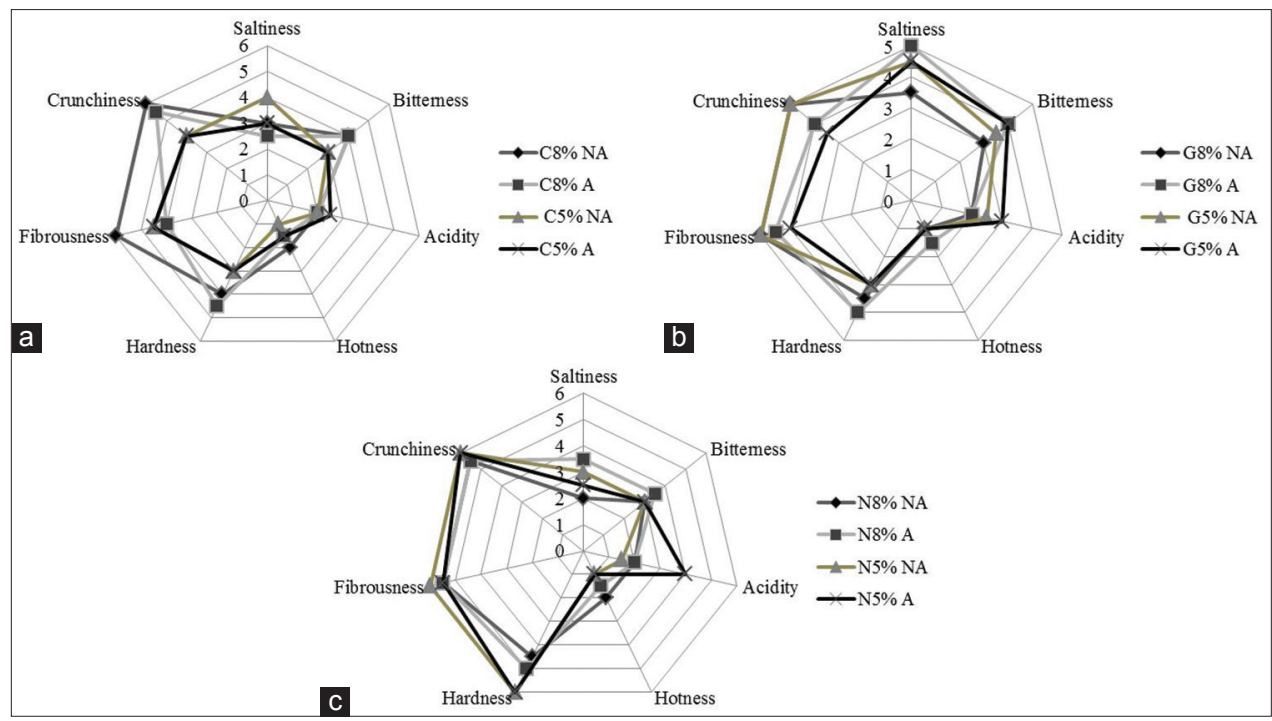

Fig 4. Sensory attributes of table olives after 240 days of fermentation in Carolea (a), Grossa of Gerace (b) and Nocellara Messinese (c) $c v$

acidification $\left(9.12 \pm 0.63 \mathrm{~g}\right.$ gallic acid $\left.\mathrm{kg}^{-1}\right)$. Not significant differences were found in the Grossa of Gerace olives among treatments. Comparing the results of fresh to the fermented olives (Table 1), it is possible to observe that the fresh olives showed higher TPC values. These values decreased during the conservation period even if they remain high especially in the Carolea cultivar (Table 6). A reduction greater than $50 \%$ occurs in the Nocellara $c v$ (23.29 \pm 2.62 in $\mathrm{N}$ and $9.12 \pm 0.63$ in N5\%A). The highest antioxidant capacity values determined with ABTS assay, were measured in Carolea $c v$ for all the treatments (the values ranged between 1892 and $2613 \mu \mathrm{M}$ Trolox), these values with is in agreement with the results of TPC and DPPH assay (the values ranged between 33 and 39\%). The lowest data were measured for Nocellara Messinese $c v$, for all the treatments and for all the antioxidant assays. The antioxidant compounds were significantly influenced by the different parameters of experimentation, only the ABTS assays was not influenced by the treatments (p>0.05), (Tab.4 b).

Positive Pearson correlations were found between TPC and the total antioxidant activity assays (ABTS and DPPH), especially in Carolea $c v$ (ABTS/TPC: $\mathrm{r}=0.848$; DPPH/ TPC: $\mathrm{r}=0.926)$ and Nocellara $c v$ (ABTS/TPC: $\mathrm{r}=0.973$; DPPH/TPC: $r=0.729)$.

\section{Sensory evaluation of table olives}

The sensory aspects are very important because have an impact on the acceptability by the consumer, particularly the gustative and kinaesthetic attribute. The results of sensory analysis are shown in Figure 4 (a, b, c). Grossa of Gerace $c v$ showed after 240 days of fermentation higher values of saltiness ( 5 in $\mathrm{G} 8 \% \mathrm{~A}$ ); the saltiness is the basic taste produced by aqueous solutions of sodium chloride.
Probably the highest perception of salty in this cultivar is due to the smaller size of the olives. Nocellara Messinese olives at the end of fermentation were characterized by the highest kinaesthetic sensations such as hardness (force required to attain the deformation of the product) with value 6 in the samples brined with $5 \% \mathrm{NaCl}$ with and without acidification. The crunchiness parameter was instead higher in all the olives of Nocellara Messinese $c v$ and in Carolea treated at $8 \% \mathrm{NaCl}$ (with and without acidification). In Geracese olives the kinaesthetic sensations were lower in most of the samples. Except for acidity, Nocellara Messinese samples possessed similar sensorial attributes with no differences due to the fermentation conditions.

\section{CONCLUSION}

This work reports an investigation on the physicochemical, sensory and antioxidant characteristics of table olives obtained from typical cultivars (Carolea, Grossa of Gerace and Nocellara Messinese) grown in Southern Italy (Calabria). The physicochemical evolution trend during fermentation was similar for all the cultivars, with the best results for the samples treated with a higher concentration of salt $(8 \%)$. Among applied treatment conditions, the olives in brines with initial $5 \%$ of $\mathrm{NaCl}$ manifested worse qualitative characteristics, in particular for the minor reduction of $\mathrm{pH}$ during fermentation. Carolea $c v$ showed the best characteristics both from the physicochemical and antioxidant point of view.

\section{Authors' contributions}

Marco Poiana and Amalia Piscopo have developed the experimental plan. Alessandra de Bruno and Angela Zappia performed the analysis. Alessandra De Bruno performed 
the computations, verified the analytical methods and discussed the results and wrote the final manuscript. Marco Poiana and Amalia Piscopo supervised the findings of this work.

\section{REFERENCES}

Aka-Kayguluoglu, A., A. Akpinar-Bayizit and O. I. Sahin-Cebeci. 2014. Evaluation of physicochemical and sensory properties of green olive pastes. Indian J. Tradit. Know. 13: 654-658.

Aponte M., V. Ventorino, G. Blaiotta, G. Volpe, V. Farina, G. Avellone, C. M. Lanza and G. Moschetti. 2010. Study of green Sicilian table olive fermentations through microbiological, chemical and sensory analyses. Food Microbiol. 27: 162-170.

Arroyo-López, F. N., J. Bautista-Gallego, J. Domínguez-Manzano, V. Romero-Gil, F. RodriguezGómez, P. García-García, A. Garrido-Fernández and R. Jiménez-Díaz. 2012. Formation of lactic acid bacteria-yeasts communities on the olive surface during Spanish-style Manzanilla fermentations. Food Microbiol. 32: 295-301.

Bondet, V., W. Brand-Williams and C. Berset. 1997. Kinetics and mechanism of antioxidant activity using the DPPH free radical method. Lebensm Wiss Technol. 30: 609-615.

Brand-Williams W., M. E. Cuvelier and C. Berset. 1995. Use of a free radical method to evaluate antioxidant activity. Lebensm. Wiss. Technol. 28: 25-30.

Brenes, M., C. Romero and A. Castro. 2004. Combined fermentation and evaporation processes for treatment of washwaters from Spanish-style green olive processing. J. Chem. Technol. Biotechnol. 79: 253-259.

Chranioti, C., P. Kotzekidou and D. Gerasopoulos. 2018. Effect of starter cultures on fermentation of naturally and alkali-treated cv. Conservolea green olives. J Food Sci. Technol. 89: 403-408.

Conte, P., G. S. G. Caponio, C. F. A. Urgeghe, L. Montanari, A. Montinaro and A. Piga. 2019. Change in quality during ripening of olive fruits and related oils extracted from three minor Autochthonous Sardinian cultivars. Emir. J. Food Agr. 31: 196-205.

Cosmai L., D. Campanella, M. DeAngelis, C. Summo, V. M. Paradiso, A. Pasqualone and F. Caponio. 2018. Use of starter cultures for table olives fermentation as possibility to improve the quality of thermally stabilized olive-based paste. LWT Food Sci. Technol. 90: 381-388.

D'Antuono, I., A. Bruno, V. Linsalata, F. Minervini, A. Garbetta, M. Tufariello, G. Mita, A. F. Logrieco, G. Bleve and A. Cardinali. 2018. Fermented apulian table olives: Effect of selected microbial starters on polyphenols composition, antioxidant activities and bioaccessibility. Food Chem. 248: 137-145.

Fadda, C., A. Del Caro, A. M. Sanguinetti and A. Piga. 2014. Texture and antioxidant evolution of naturally green table olives as affected by different sodium chloride brine concentrations. Grasas Aceites, 65.

Fernández-Diez, M. J., R. Castro, A. Fernández, F. G. Cancho, F. G. Pellissó, M. N. Vega, A. H. Moreno, I. M. Mosquera, L. R. Navarro, M. C. D. Quintana, F. S. Roldàn, P. G. Garcìa and A. Castro. 1985. Biotecnologì de la Aceituna de Mesa, CSIC, Spain.

Gamli, Ö. F. 2016. The health effects of oleuropein, one of the major phenolic compounds of olives. Olea europaea L. Ital. J. Food Sci. 28: 178-189.

Garcìa, P., C. Romero and M. Brenes. 2018. Bioactive substances in black ripe olives produced in Spain and the USA. J. Food Compos. Anal. 66: 193-198.
Garrido Fernández A., M. J. Fernández Díez and M. R. Adams. 1997. Table Olive Production and Processing. Vol. 67. Chapman and Hall, United Kingdom, p. 109.

Giuffrè, A. M. 2017. Biometric evaluation of twelve olive cultivars under rainfed conditions in the region of Calabria, South Italy. Emir. J. Food Agric. 29: 696-709.

IOC. 2000. International Olive Oil Council World Catalogue of Olive Cultivars. IOC, Madrid, Spain.

IOC. 2004. International Olive Oil Council Trade Standard Applying to Table Olives. IOC, Madrid, Spain.

IOC. 2011. International Olive Oil Council Sensory Analysis of Table Olives. Document COI/OT/MO No 1/Rev. 2. IOC, Madrid, Spain.

IOC. 2016. International Olive Council World Table Olive Figures. Available from: http://www.internationaloliveoil.org/estaticos/ view/132-world-table-olivefigures.

Maldonado, M. B., C. A. Zuritz and N. Miras. 2008. Influence of brine concentration on sugar and sodium chloride diffusion during the processing of the green olive variety Arauco. Grasas Aceites. 59: 267-273.

Medina, E., C. Romero, M. Brenes, P. García, A. de Castro and A. García. 2008. Profile of anti-lactic acid bacteria compounds during the storage of olives which are not treated with alkali. Eur. Food. Res. Technol. 228: 133-138.

Mele, M. A., M. Z. Islam, H. M. Kang and A. M. Giuffrè. 2018. Preand post-harvest factors and their impact on oil composition and quality of olive fruit. Emir. J. Food Agric. 30: 592-603.

Othman, N. B., D. Roblain, N. Chammen, P. Thonart and M. Hamdi. 2009. Antioxidant phenolic compounds loss during the fermentation of Chétoui olives. Food Chem. 116: 662-669.

Pires-Cabral, P., T. Barros, P. Nunes and C. Quintas. 2018. Physicochemical, nutritional and microbiological characteristics of traditional table olives from Southern Portugal. Emir. J. Food Agric. 30: 611-620.

Piscopo, A., A. De Bruno, A. Zappia and M. Poiana. 2014. Antioxidant activity of dried green olives (Carolea cv.). LWT-Food Sci. Technol. 58: 49-54.

Piscopo, A., A. De Bruno, A. Zappia, C. Ventre and M. Poiana. 2016a. Characterization of monovarietal olive oils obtained from mills of Calabria region (Southern Italy). Food Chem. 213: 313-318.

Piscopo, A., A. De Bruno, A. Zappia, and M. Poiana. 2016b Increase in antioxidant activity of brined olives (Carolea cv.) thermally treated in different packaging types. Eur. J. Lipid Sci. Technol. 118: $1132-1140$.

Piscopo, A., A. Zappia, A. De Bruno and M. Poiana. 2018a. Effect of the harvesting time on the quality of olive oils produced in Calabria. Eur. J. Lipid Sci. Technol. 120: 1700304.

Piscopo, A., A. De Bruno, A. Zappia, G. Gioffre, N. Grillone, R. Mafrica and M. Poiana. 2018b. Effect of olive storage temperature on the quality of carolea and ottobratica oils. Emir. J. Food Agric. 30: 563-572.

Re, R., N. Pellegrini, A. Proteggente, A. Pannala, M. Yang and C. Rice-Evans. 1999. Antioxidant activity applying an improved ABTS radical cation decolorization assay. Free Radic. Biol. Med. 26: 1231-1237.

Rodríguez-Gómez, F., M. Á. Ruiz-Bellido, V. Romero-Gil, A. BenítezCabello, A. Garrido-Fernández and F. N. Arroyo-López. 2017. Microbiological and physicochemical changes in natural green heatshocked aloreña de málaga table olives. Front. Microbiol. 8: 2209.

Romeo, F. V., S. De Luca, A. Piscopo, E. Perri and M. Poiana. 2009. Effects of post-fermentation processing on the stabilisation of naturally fermented green table olives (cv nocellara etnea). Food Chem. 116: 873-878. 
Romeo, F. V., A. Piscopo and M. Poiana. 2010. Effect of acidification and salt concentration on two black brined olives from Sicily (cv Moresca and Giarraffa). Grasas Aceites. 61: 1-3.

Romeo, F. V., A. Piscopo and M. Poiana. 2012. Effect of drying, chemical and natural processing methods on black biancolilla olives. Grasas Aceites. 63: 223-230.

Romero, C., M. Brenes, K. Yousfi, P. Garcia, A. Garcia and A. Garrido. 2004. Effect of cultivar and processing method on the contents of polyphenols in table olives. J. Agric. Food Chem. 52: 479-484.

Ryan, M. and K. Robards. 1998. Critical review. Phenolic compounds in olives. Analyst. 123: 31R-44R.
Sánchez, A. H., A. López-López, A. Cortés-Delgado, V. M. Beato, E. Medina, A. de Castro and A. Montaño. 2018. Effect of postfermentation and packing stages on the volatile composition of Spanish-style green table olives. Food Chem. 239: 343-353.

Sicari, V., A. M. Giuffrè, L. Louadj and M. Poiana. 2010. Evolution of phenolic compounds of virgin olive oil during 12 months storage. Riv. Ital. Delle Sostanze Grasse. 87: 109-116.

Sidari, R., A. Martorana and A. De Bruno. 2019. Effect of brine composition on yeast biota associated with naturally fermented nocellara messinese table olives. LWT Food Sci. Technol. 109: 163-170. 